\title{
PLANTS AND THEIR SEASONAL CHANGES: TEACHING BIOLOGY IN PRIMARY SCHOOL USING THE SCIENTIFIC METHOD
}

\author{
Alessandra Gaiotto ${ }^{1}$, Paola Bisaccia ${ }^{2}$, Marco Bonato ${ }^{3}$, Paola Irato ${ }^{4}$, Francesca \\ Corrà $^{5}$, Gianfranco Santovito ${ }^{6 *}$ \\ ${ }^{1}$ Dr, University of Padova, ITALY, aless.gaiotto@hotmail.it \\ ${ }^{2} \mathrm{Dr}$, University of Padova, ITALY, bisaccia.paola@gmail.com \\ ${ }^{3}$ Dr, University of Padova, ITALY, marco.bonato@unipd.it \\ ${ }^{4}$ Dr, University of Padova, ITALY, paola.irato@unipd.it \\ ${ }^{5} \mathrm{Dr}$, University of Padova, ITALY, francesca.corra@unipd.it \\ ${ }^{6} \mathrm{Dr}$, University of Padova, ITALY, gianfranco.santovito@unipd.it \\ ${ }^{*}$ Corresponding Author
}

\begin{abstract}
With a view to the active learning, that makes the students protagonist, responsible and aware of the learning process, the present study presents an experimental work designed to demonstrate the usefulness and the validity of the scientific method as the basic element of the teaching of Life Sciences.

Scientific training adopts an inductive approach to knowledge that allows us to observe, imagine, discover, verify, generalize, providing the tools needed to understand the reality. This research focused on the study of seasonality in the first class of a Primary School in Treviso (Italy), using a teaching approach based on direct field exploration and planning activities in which the sensory perceptual aspect is only the starting point. Those activities were based on both the observational comparative method (characteristic of Evolutionary Biology), and the experimental method (a feature of Functional Biology).

Prior to the experimental out a preliminary investigation work was carried, involving the teachers of Natural Sciences and Experimental of some Italian Primary Schools. This survey allowed to paint a partial picture of how it the teaching of the Biology is performed, with particular reference to the seasonality, which was the starting point to develop and test a didactic approach of adequate originality.

The addressed topics were divided in four stages corresponding to the seasons, and covered aspects of plant morphology (leafs, vascular tissues, flowers, fruits), plant physiology (the color changes of the leafs, leaf abscission, plant nutrition, fruit development) and the concept of biodiversity.

The obtained results showed that, using the scientific method and laboratory tools such as the stereoscope and the optical microscope, conceptualizations planned for second cycle of the Primary School can be met with success in the first class, helping to reach the programmed goals optimally and often excellently, facilitating the achievement of competences such as the use of a correct scientific nomenclature. With this approach, the young students were motivated, stimulated, intrigued, and this potentially provides a meaningful, authentic and transferable Lifelong Learning and the development of a scientific culture together with an early interest in the Sciences.
\end{abstract}

Keywords: laboratory didactics, life sciences, primary school, musculoskeletal system, scientific method.

\section{INTRODUCTION}

In teaching Life Sciences there is neither a starting point, nor a default route. Teaching Biology means to move the interest of children towards natural phenomena and discovery. Obviously, examining data and 
events according to a reticular itinerary (Andena, 2007), during which prevail observation and qualitative reasoning for a learning of search and induction. With the sciences you train to understand and adapt the ideas to the facts of reality. At school, the ideas will be those spontaneous of students on things they want to discover and to understand.

A so complex vision of the Biology implies a teaching that goes towards students, that solicits their personal experiences, that can be reprocessed and that depart from everyday life. Attention is not a default knowledge, but it's a useful tool to know, observe, understand and compare. Knowledge is not a linear sequence, but an infinite cognitive network, organized by logical structures corresponding to facts and concepts.

Narrowing the field of investigation, Biology is a science that studies the continuous change in time and space of each living species (Arcà, 1993).

The subject shall solicit experiences that students can elaborate personally through the construction of attractive and stimulating contexts (Arcà, 1993). The main objective of basic scientific training is the ratio cognitive, individual and socialized with reality, which is characteristic of the culture in which children are immersed since birth, and in which they will grow up and live (Alfieri et al., 1995). The teacher should direct the development and the variety of ways of looking, thinking, speaking, using cognitive and representative strategies.

The scientific method is the core of all activities of this work: it's a method of investigation based on observations of objects and events (phenomena, experiments), on spontaneous questions (hypothesis), on research and on the construction of models that give answers and allow to continue the investigation, extending it to phenomena related to the starting point (Santovito, 2015). The communication to other of the path and the found explanations is also part of the research. The new models will be compared with the already acquired knowledge and with new experiments. The observations can be made with tools that extend the senses, such as magnifying lenses, stereoscopes and optical microscopes.

This method is characterized by the formulation of an initial hypothesis that contributes to the research and to the construction of adaptation in cognitive elaboration of reality (Santovito, 2015). This is what drives the transition from the concrete to the theory, through processes of schematization, formalization, recognition of relationships between systems and variable interpretation.

The present work aims to demonstrate the usefulness and validity of the scientific method as the basic element of the teaching of Life Sciences. It is wanted to develop the concept of seasonality, with particular reference to plants. For this purpose, activities with both the observational-comparative method (Evolutionary Biology) and with the experimental method (Functional Biology) have been designed and implemented.

The route has been divided in four phases, formally corresponding to the four seasons, and each step included various activities, for the study of plant morphology (leaf, flower, fruit) and physiology (abscission leaf, the change of colour of leaf, the nourishment of plants, the transformation of flowers in fruits).

Specifically, we wanted to demonstrate how conceptualizations planned for older students can be also addressed in the first class of the Primary School, thanks to the use of the scientific method and tools such as the stereoscope and the optical microscope.

Before starting the experimental teaching, a survey involving teachers of Natural and Experimental Sciences of all the primary schools of the Comprehensive has been made. The results obtained with the survey were used to verify the originality of the present educational approach.

\section{MATERIALS AND METHODS}

\subsection{Field of work}

The experimental work has been carried out in the class 1C of the Primary School "Anna Frank" (Comprehensive Institute number 3 "Felissent" in Treviso, Italy), which is in the district of Sant'Angelo, area south-east of Treviso city. The complex is near the Park of Villa Letizia, where it was possible to perform the exploration of the territory during several months. Specifically, the Park is part of the Natural Regional Park of the River Sile that covers an area of 4,152 hectares, between the provinces of Padua, Treviso and Venice. It consists of several oases and natural sites and includes some springs.

In the class $1 \mathrm{C}$ there were thirteen pupils, and this aspect allowed us to work more easily, having more important relationships with each student. The activity steps are summarized in Tab.1. 
Tab.1. The steps of the experimental activity.

\begin{tabular}{|c|c|}
\hline & $\begin{array}{c}\text { THE SCIENTIFIC METHOD IN THE TEACHING OF LIFE SCIENCES } \\
\text { THE SEASONALITY CHANGES IN PLANTS }\end{array}$ \\
\hline & STEP 1: AUTUMN \\
\hline $\begin{array}{r}\text { Activ } \\
- \\
- \\
- \\
- \\
-\end{array}$ & $\begin{array}{l}\text { Direct exploration of the territory; } \\
\text { Description, classification of leaves and identification of plants they belong to; } \\
\text { The colour of leaves: from green to red; } \\
\text { The fall of leaves; } \\
\text { Verification. }\end{array}$ \\
\hline & STEP 2: WINTER \\
\hline $\begin{array}{r}\text { Activ } \\
- \\
- \\
-\end{array}$ & $\begin{array}{l}\text { Direct exploration of the territory; } \\
\text { Conducting tissues and the concept of capillarity; } \\
\text { Verification. }\end{array}$ \\
\hline & STEP 3: SPRING \\
\hline $\begin{array}{r}\text { Activ } \\
- \\
- \\
-\end{array}$ & $\begin{array}{l}\text { Direct exploration of the territory; } \\
\text { The structure of the flower and the pollen; } \\
\text { Verification. }\end{array}$ \\
\hline & STEP 4: SUMMER \\
\hline $\begin{array}{r}\text { Activ } \\
- \\
- \\
-\end{array}$ & $\begin{array}{l}\text { Stages of development: from the flower to the fruit; } \\
\text { The structure of the fruit; } \\
\text { Verification. }\end{array}$ \\
\hline
\end{tabular}

\section{RESULTS}

\subsection{Description and Classification and Changes in Colour of Leaves}

After the direct exploration of the territory, the discussion and the drawing of the observed environment, each child chose a leaf among those sampled for the first activity. The pupils were asked to observe, touch and smell them. After this first individual phase, the students described their leaf, in terms of lamina, colour, margin, transience, smell and touch perception.

After the description of the leaves we started the work of classification using several boxes, where we stored the leaves. Many children decided that the parameter of classification would be the margin shape.

In a billboard, we exposed the leaves of the main trees of the park, those sampled by the class during the exploration of the territory. The pictures of the trees were taken in the park by the teacher, to improve the recognition and the significant learning. Each student had the charge of identifying its leaf and to name of the tree from which it originates (Fig. 1). Furthermore, they verified on the billboard the correctness of their perceptions regarding the description given before. The next proposed activity was to complete the so-called "identity card" of the leaf.

To introduce the activity on the colour change of the leaves, we firstly stimulated a discussion on this phenomenon. The class was then brought to the laboratory to test what happens inside the leaf. Firstly, we prepared an experiment with the aim to make it clear that chlorophyll is a green substance that can be removed by plants. In a jar filled with alcohol we put spinach leaves, and after a few minutes the alcohol began to be coloured in green and the leaf colour become more and more pale, especially on margins. 

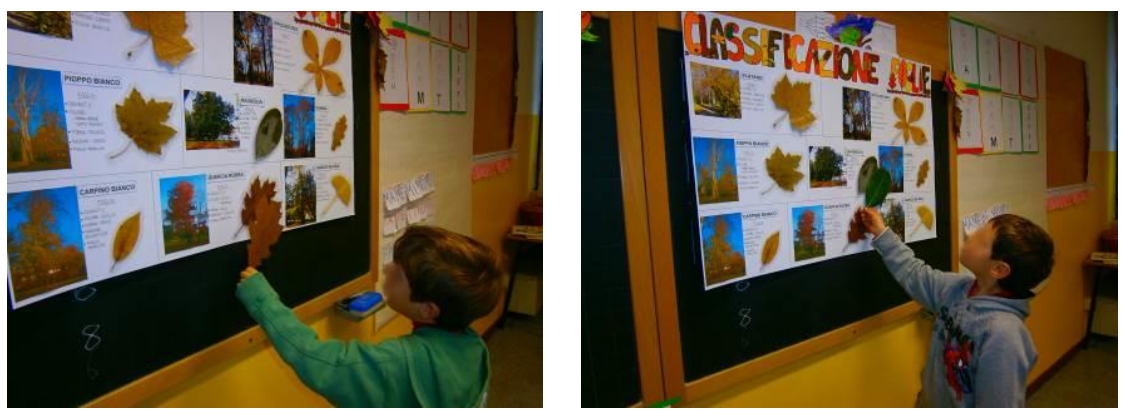

Fig. 1. Autumn - leaves classification: identification leaf - tree

After a discussion, the students realized that the green colour corresponds to the chlorophyll, and that this is a substance that can be removed from leaves. By removing this green substance, emerge other colours (yellow, red), which are always present in leaves, but not visible. These colours are called "pigments" and they are also present in other plants, such as some types of fruit (strawberry) and vegetables (onion).

The concept that pigments of different colours are present in a leaf has been enforced by the obseration by optical microscopy of chlorophyll and anthocyanins contained in the film of red onion (Fig. 2). The activity was concluded with an oral summarization of the learned concepts.
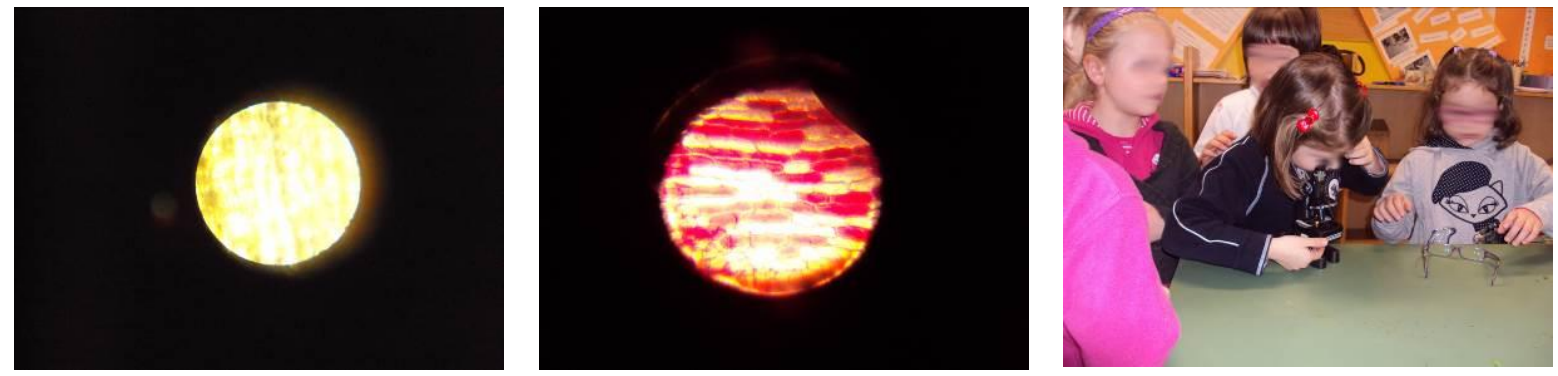

Fig. 2. Autumn - the colour of the leaves: optical microscope

\subsection{Conducting Tissues and Concept of Capillarity}

During the discussions made after the second exploration of the territory, we talked about the nourishment of the trees, so in the activities designed for the winter season has included the study of the conducting tissues (particularly tracheae and tracheids) and the concept of capillarity.

After the discussion the children hypothesized that within the plants there are "tubes" extending from roots to leaves, inside of which flows the food. To verify their hypotheses an experiment has been proposed, putting the celery in a pot with ink coloured water (three pots with ink of three different colours) and waiting for the partial colouring of the leaves. After three days, all the material was transferred to the laboratory, where we analysed the results. To understand how the colour has come up to the leaves, in order to enforce the bundles of conduction and the tracheae, responsible for the transport of nutrients (in this case ink), celery was cut cross-sectional and longitudinal with a razor blade. In Fig. 3 there are some moments of macroscopic observation, in which the students are trying to understand how plants are nourished and with such structures.

After the macroscopic observation of the tracheae, thin longitudinal section of xylem (vascular tissue of the plant) of celery has been cut with a razor blade, in order to make even a microscopic observation. The pupils had the possibility to observe the xylem at optical microscope, distinguishing different thickening on the cell walls, forming rings, spirals, oblique-mesh, depending on the function of the "pot".

Then we stimulated a discussion about the diameter of the trachea. After the first hypothesis an experiment on capillary action has been proposed, which allowed to understand how the ascent of the liquid is inversely proportional to diameter of the capillary tube. 

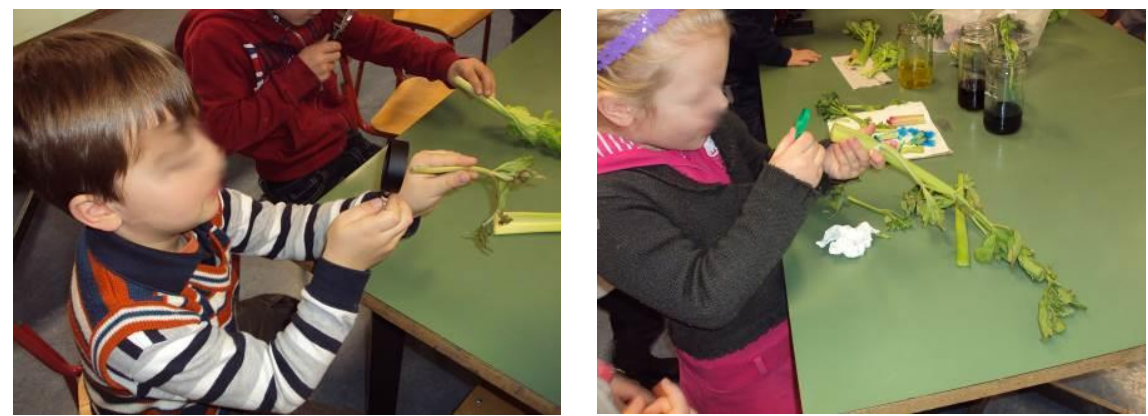

Fig. 3. Winter - capillarity: macroscopic observation of tracheae

\subsection{Flower Morphology and Pollen}

After the third seasonal meeting for the area exploration, the discussion and the representation of the explored environment, a specific activity has been proposed, more oriented to the peculiarities of the spring.

Before starting the laboratory activity, a diagnostic check on the structure of the flower was given, making it draw one, without clause. The aim is to redraw it at the end of the route and comparing the two tests, to verify if and how much the children's knowledge on the subject are changed.

Each child received a flower in the classroom: among them there were both flowers collected from students during the exploration and others taken by the teacher.

We explained to the kids that the goal of the activity was the study of the flower structure, and then we stimulated the observation of each flower, using magnifying lenses. Moreover, we encouraged the pupils to manually separate the different parts of the flower (Fig. 4). At the same time, we stimulated a free conversation (led by the teacher) among the students, to compare and share the identification of the structural parts. The different components of the flower were disposed on the working desk as to distinguish them.
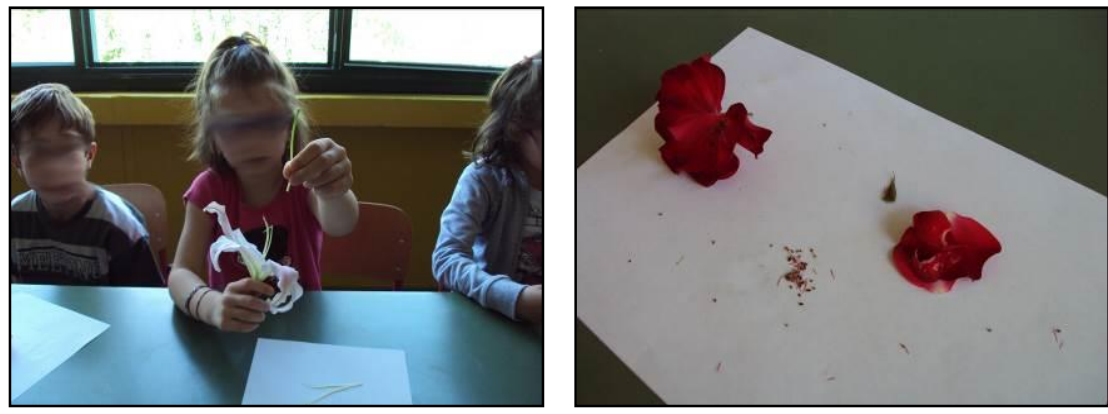

Fig. 4. Spring - flower structure: observation - comparison

Once each child identified the structural parts of his flower, separating them on a sheet, we started a discussion for the comparison. After this first phase, the children gave their own terminology to all components and subsequently we give them the correct name of each part. A simple game was used to consolidate the terms: the teacher named the parts in random order, and each pupil touched and picked up the corresponding part of the flower that had been assigned.

Eventually it was hung a poster with an illustration of a flower, lily, with the nomenclature of all parts, to carry out a review and to use it during the next activity. The next proposal was to fill a large billboard with a double-entry table, previously made by the teacher, attaching the parts of the all assigned flowers: horizontally were sorted all the flowers of the students and in vertical the various constituent parts (Fig. 5).

As the pupils ended to glue the various parts of its flower on the billboard, the next laboratory activity was the observation by the stereoscope of components of the flowers, comparing the elements of different species by shape and functions (Fig. 6).

For example, the teacher explained to the pupils that the function of the pistil is to capture pollen grains (on the stigma), which will drop along the pistil until it reaches the ovary, inside of which the seed will originate, so that the function of flowers is the reproduction of plants. We asked the students where they saw the pollen, both naked eye and by stereoscope. Some of them noticed it on the pistil, someone else on the stamen (anther). 

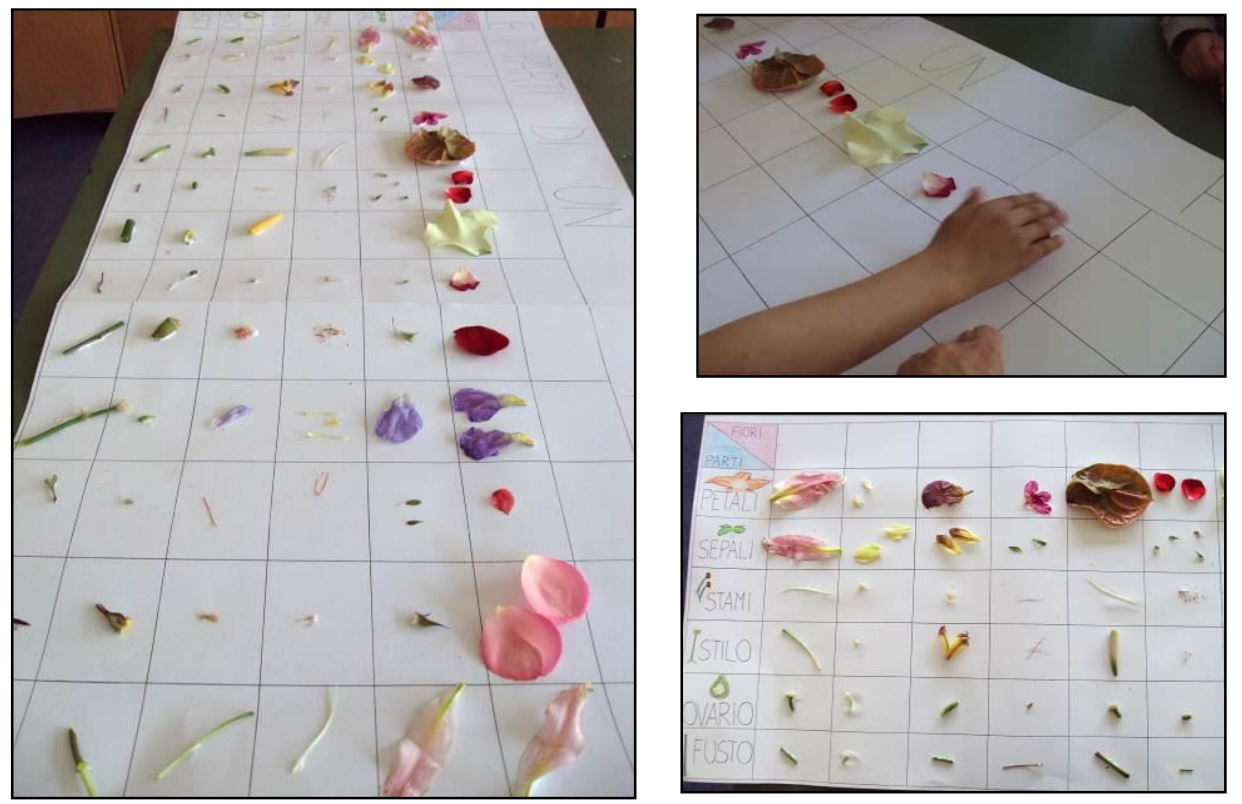

Fig. 5. Spring - flower structure: billboard "the parts of a flower"
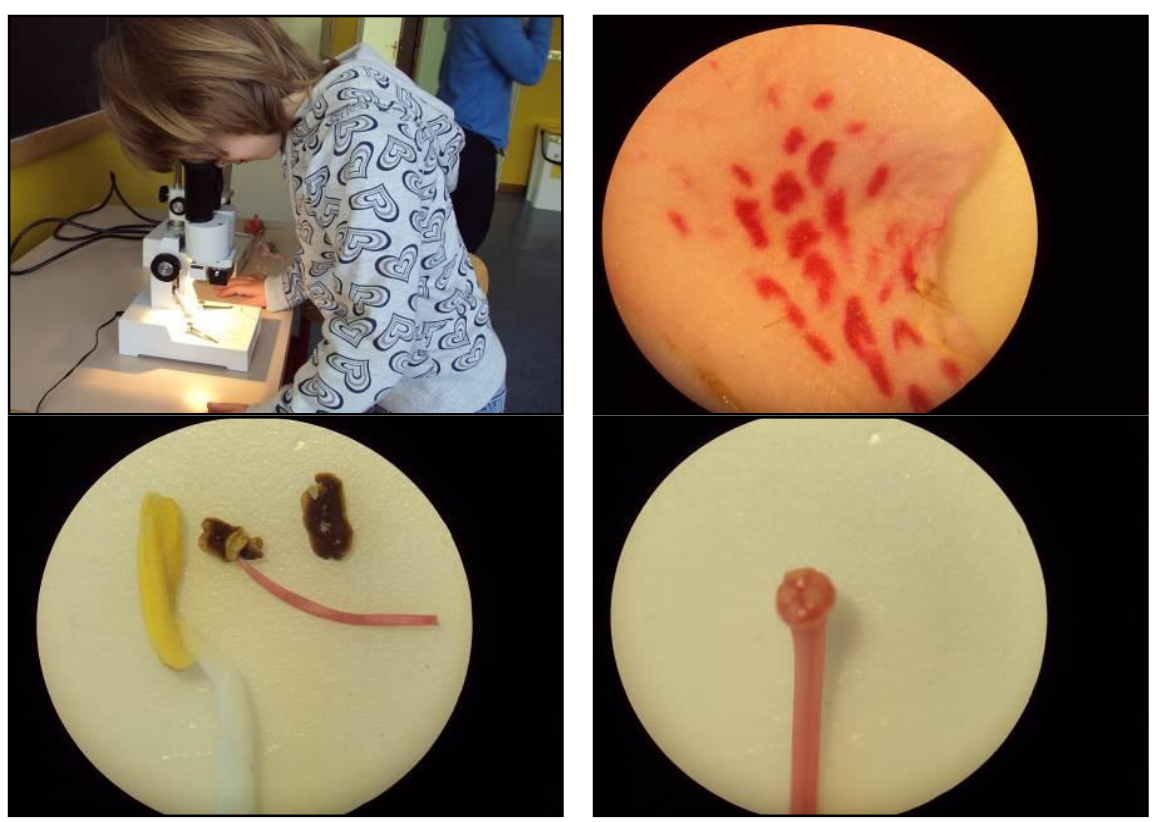

Fig. 6. Spring - flower structure: observation with the stereoscope

Because different flowers have also different pollens, the students had the possibility to observe by an optical microscope various pollens, someone white and other ones bright yellow (Fig. 7).
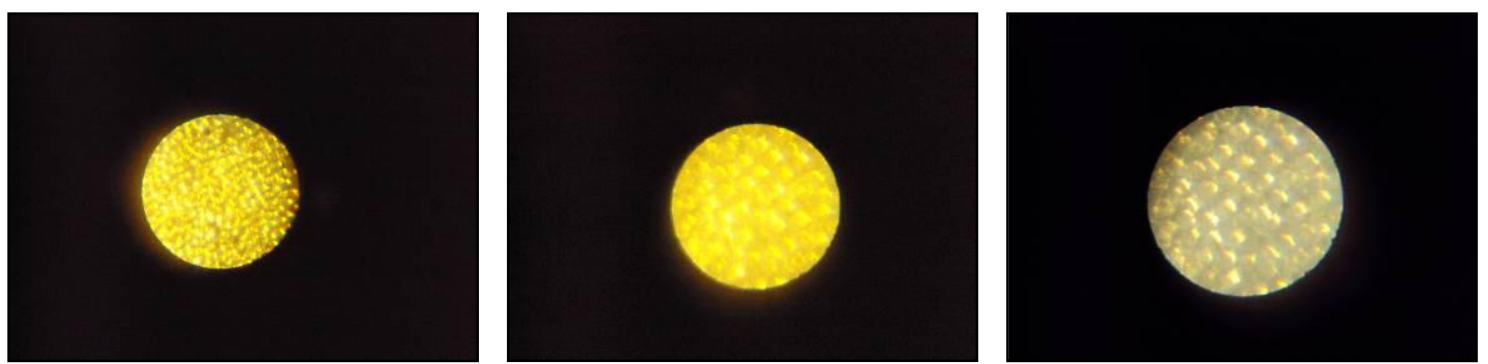

Fig. 7. Spring - the pollen: images at the microscope

As mentioned above, to verify the learnings, pupils drew their flower again, evaluating the presence of other constituent elements as well as stem and petals. Fig. 8 shows an example of flower designed "before" and "after" the activities. The $46 \%$ of the children drew both stamens, stylus, ovary and sepals. 

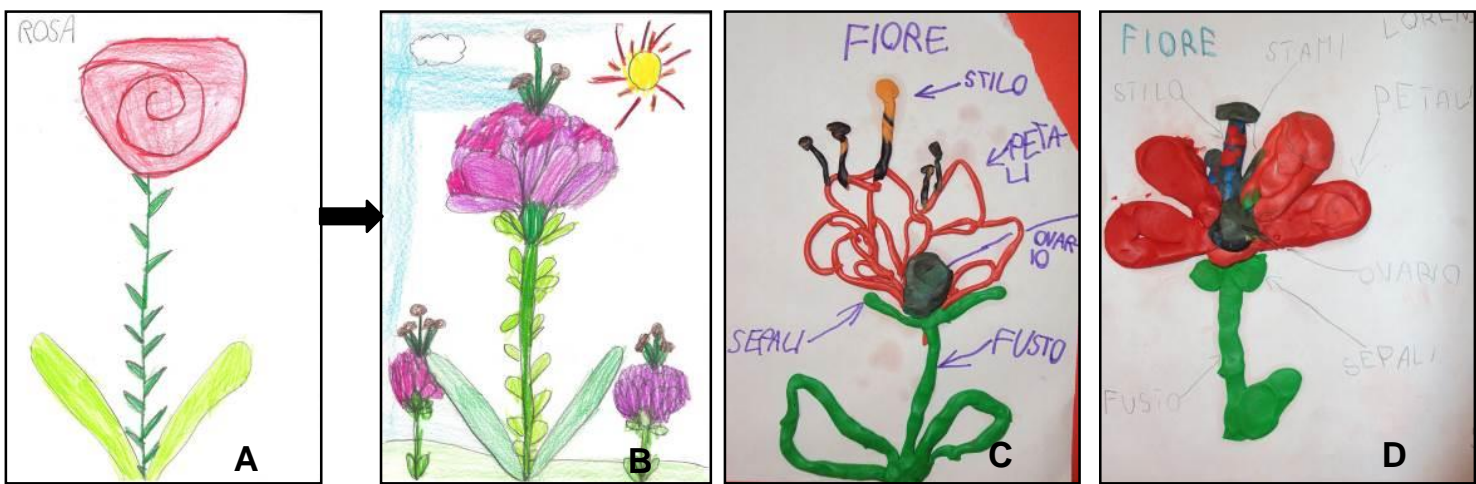

Fig. 8. Spring - Test: combination of the two images of the flower (A) "before" and (B) "after" the laboratory activity. (C-D) Reproduction of flower with modelling clay

\subsection{From Flower to Fruit: Stages of Development and Morphology}

The pupils were arranged around a large table with a plant of Calamondin (Citrofortunella mitis) in the middle. The class began to observe and touch the plant, noting different formations of the Calamondin, someone were green, small and firm to the touch, some other bigger, orange and soft to the touch (Fig. 9). The common hypothesis was that the fruit origins from this formation.
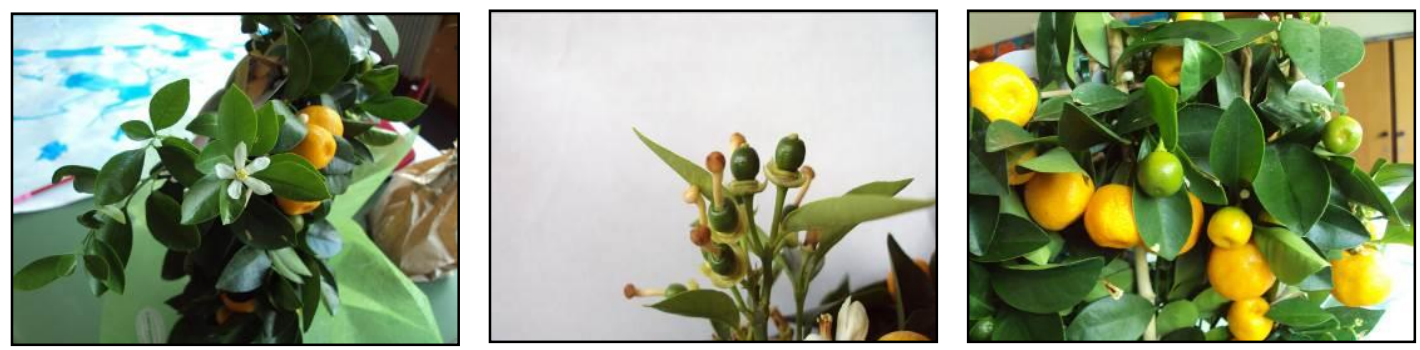

Fig. 9. Summer - from flower to fruit: observation of Calamondin (Citrofortunella mitis)

The teacher asked the students if, starting from their hypothesis of evolution from flower to fruit (ontogeny), they can tell from which part of the flower the fruit has its origin. After reordering ideas about the stages of Calamondin fruit formation, the discussion was carried to understand which is the fruit function (protection of seeds, but not only) and why they take form. Afterwards, we started an observation with the stereoscope, particularly of the enlarged ovary at the different stages of development. The pupils opened some ovaries to verify the presence of seeds inside.

For the study of fruit structure, the students sat around the tables of the laboratory and each of them received a different fruit. The children began to look and touch it, to express their first impressions on touching, smelling and hearing. Already these perceptions gave an idea of the diversity of the different fruits. We asked the class to open the fruits and to select the different parts (Fig. 10), and then the teacher proceeded to call each component with the correct nomenclature (epicarp, mesocarp, endocarp, seed).
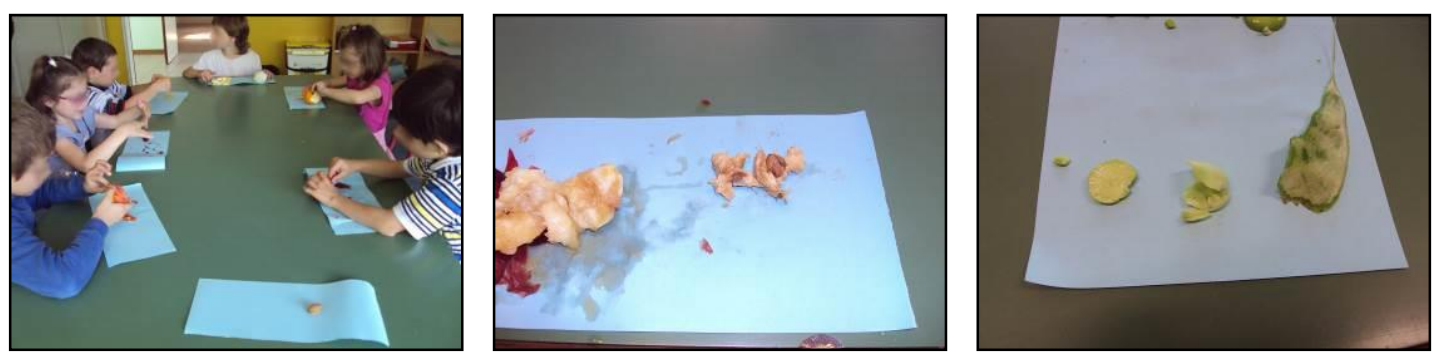

Fig. 10. Summer - The parts of the fruit: epicarp, mesocarp, endocarp, seed

The various parts of the fruits were observed by the stereoscope, in order to allow a more accurate analysis of the characteristics of each one.

During the last meeting, students had the task of drawing the fruit they previously analysed and to build it with modelling clay (Fig. 11). 

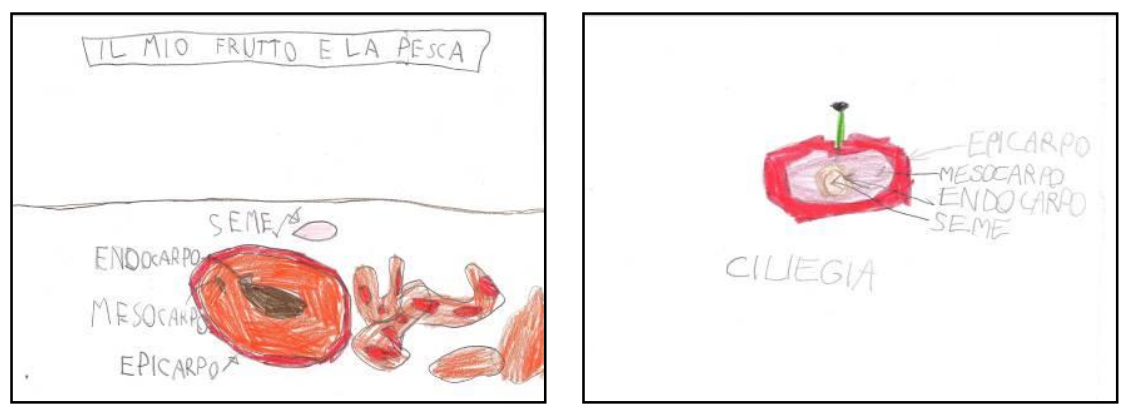

Fig. 11. Summer - draw of a fruit.

\section{DISCUSSION}

In the World and European scene, many studies analysed what are the most significant approaches to improve the learning (Gaiotto et al., 2013; Tonon et al., 2013; Pavan and Santovito, 2014; Zandonella et al., 2014; Toninato and Santovito, 2015; Trevisan and Santovito, 2015; Gaiotto and Santovito, 2016; Rossi and Santovito, 2016; Capparotto et al., 2017; Favaron et al., 2017; Lago et al., 2017; Meneghetti et al., 2017; Barbacovi et al., 2018; Fassinato et al., 2018; Forlin et al., 2018; Grando et al., 2018a, 2018b; Tura et al., 2018; Chiesa et al., 2019; Gallina et al., 2019; Lui et al., 2019; Palmieri et al., 2019; Corbolino et al., 2020; Zanata and Santovito, 2020). Nevertheless, these practices were found not used in the Italian school.

The focus of this work is the teaching of seasonality, with reference to plants, through the scientific method. The first peculiarity is that this project is adapted to a first class of Primary School, when teachers usually don't use tools such as a microscope or stereoscope, with the justification that children at that age are too young to use these tools, preferring simpler activities, based only on the five senses (Maurizi, 2010; Porazzi, 2011). The most important aim of this experimental approach was to demonstrate that, thanks to these tools, children can learn, and that the teaching activity may also include arguments normally proposed with older children. Analysing the obtained results, we can assert that it is not the concept itself to determine the right age for teaching these subjects, but most important are the goals that you have, the used method and the motivation related to it.

Especially in the age ranging from five to seven years, the child needs to experience, handle, observe, explore, discover and have curiosity (Arcà, 1993). For this reason, we used as starting point of each seasonal activity the exploration of the territory, in order to understand characteristics and changes, that are the priority issues and are fundamental for the preparation of the study of more specific concepts in the laboratory. In addition, we enforced the concepts of the seasonality with several activities of experimentation and observation-comparison. Seasonality has been the starting point to develop the teaching of Life Sciences.

Another important element of my experimentation is the use of specific terms: it is not always correct to name structures, phenomena, characteristics in a simplified way, because the students will have to "relearn" them with other nomenclature. If you offer an abstract teaching, based on the exercises usually proposed by the textbook, the class will have trouble to remember the terminology. With this work we demonstrate that the children will be able to use an appropriate lexicon observing and discovering by himself the nature.

In conclusion, the direct experience of the biological reality has proven to be of great interest to the students. This is very important for a meaningful learning and for the stability and transferability of experiences to other contexts, that are the target required in a curriculum designed with the goal of the Lifelong Learning.

The direct exploration in the territory, the activities of observation, comparison and experimentation, and the use of scientific instruments (stereoscope, microscope) enabled to reach optimal, and often excellent, objectives.

Of course, all the projected activities can be proposed (with appropriate changes) to students of different ages, but the observations presented in this work show that this kind of approach allows to get great results, even if proposed to children of the first class of Primary School.

\section{REFERENCE LIST}

Alfieri, L., Arcà, M. \& Guidoni, P. (1995). Il senso di fare scienze: Un esempio di mediazione tra cultura e 
scuola. Bollati Boringhieri Editore, Torino.

Andena, T. (2007). Insegnare con i concetti le scienze. Franco Angeli Editore, Milano.

Arcà, M. (1993). La cultura scientifica a scuola. Franco Angeli Editore, Milano.

Barbacovi, V., Santovito, G. \& Irato, P. (2018) Little scientists for large discoveries: an experimental approach to survey the world with classes ii of the primary school - The observation and study of plant life. In: EDULEARN18 Proceedings, IATED, Valencia. https://doi.org/10.21125/edulearn.2018.1579

Capparotto, A., Bramuzzo, S., Callegaro, E., Poloni, E., Corrà, F. \& Santovito G. (2017) The didactics of biology in primary school: an innovative approach to skeletal system teaching in fifth class based on comparative vertebrate anatomy. In: INTED2017 Proceedings, IATED, Valencia. http://doi.org/10.21125/inted.2017.0935

Chiesa, E., Irato, P. \& Santovito, G. (2019) The circulatory system of vertebrates and invertebrates: an empirical research to introduce in the fourth class the treatment of animal morphology in a comparative key. In: INTED2019 Proceedings, IATED, Valencia. https://doi.org/10.21125/inted.2019.0391

Corbolino, N., Bisaccia, P., Corrà, F., Bonato, M., Irato, P. \& Santovito G. (2020) The vegetable garden. An instrument for sustainable development education and care pedagogy. In: INTED2020 Proceedings, IATED, Valencia. https://doi.org/10.21125/inted.2020.1282.

Fassinato, C., Nicorelli, E., Corrà, F., Irato, P., Guidolin, L. \& Santovito G. (2018) An innovative approach to deal with biodiversity at school with its investigation in different environments. In: EDULEARN18 Proceedings, IATED, Valencia. https://doi.org/10.21125/edulearn.2018.0717

Favaron, A., Ancona, E., Bramuzzo, S., Callegaro, E., Guidolin, L., Irato, P. \& Santovito, G. (2017) An innovative teaching approach to circulatory and skeletal systems based on comparative vertebrate anatomy and physiology. In: EDULEARN17 Proceedings, IATED, Valencia. http://doi.org/10.21125/edulearn.2017.1015

Forlin, E., Santovito, G., Guidolin, L. \& Irato, P. (2018) Citrus fruits. Course to educate to scientific curiosity. In: EDULEARN18 Proceedings, IATED, Valencia. https://doi.org/10.21125/edulearn.2018.1573

Gaiotto, A., Tonon, S. \& Santovito, G. (2013) The scientific method in the teaching of life sciences in primary school, The plants and their seasonal changes". In EDULEARN13 Proceedings, pp. 4226-4235.

Gaiotto A., Santovito G. (2016) An innovative didactic approach to the study of invertebrate animals in primary school. In: EDULEARN16 Proceedings, IATED, Valencia. http://doi.org/10.21125/edulearn.2016.1284

Gallina, S., Irato, P. \& Santovito, G. (2019) Inquiry into animal tracks: an experimental application of IBSE inquiry based science education- approach in the ecological field in primary school. In: INTED2019 Proceedings, IATED, Valencia. https://doi.org/10.21125/inted.2019.0089

Grando, G., Bramuzzo, S., Irato, P., Guidolin, L., Ferrari, L. \& Santovito, G. (2018) Introduction to the world of insects: a didactic research in kindergarten. In: INTED2018 Proceedings, IATED, Valencia. https://doi.org/10.21125/inted.2018.1066

Grando, G, Bramuzzo, S., Callegaro, E., Guidolin, L., Irato, P. \& Santovito, G. (2018) Who is afraid of insects? A didactic research in the biological field in kindergarten. In: EDULEARN18 Proceedings, IATED, Valencia. https://doi.org/10.21125/edulearn.2018.0724

Lago, A., Masiero, S., Bramuzzo, S., Callegaro, E., Poloni, E., Corrà, F. \& Santovito G. (2017) Exploring microbiology and biotechnologies: a laboratory approach to the study of yeasts and bacteria in primary school. In: INTED2017 Proceedings, IATED, Valencia. http://doi.org/10.21125/inted.2017.0992

Lui, F., Irato, P. \& Santovito, G. (2019) Discovering living organisms: a didactic research to introduce biology in kindergarten. In: EDULEARN19 Proceedings, IATED, Valencia. https://doi.org/10.21125/edulearn.2019.1040

Maurizi, L. (2010). II mondo attorno a me. La Vita Scolastica, 5, 44-45.

Meneghetti, G, Bramuzzo, S., Callegaro, E., Guidolin, L., Irato, P. \& Santovito G. (2017) The kingdom of fungi in primary school: an educational research in biology field. In: EDULEARN17 Proceedings, IATED, Valencia. https://doi.org/10.21125/edulearn.2017.1023 
Palmieri, G., Irato, P., Nicolosi, P. \& Santovito, G. (2019) A day at the museum. Laboratory teaching in the Museum of Zoology at the University of Padua for primary school. In: EDULEARN19 Proceedings, IATED, Valencia. https://doi.org/10.21125/edulearn.2019.1037

Pavan, C. \& Santovito, G. (2014) The laboratory didactics in the teaching -learning processes of life sciences. an educational project on microorganisms in the alimentation in primary school. In: EDULEARN14 Proceedings, IATED, Valencia, pp 7546-7555.

Porazzi, E. (2011). I fiori. La Vita Scolastica, 15, 61-62.

Rossi, E. \& Santovito, G. (2016) Introduction to Mendelian genetics in primary school. In EDULEARN16 Proceedings, IATED, Valencia. http://doi.org/10.21125/edulearn.2016.1274

Santovito, G. (2015) Insegnare la biologia ai bambini. Dalla scuola dell'infanzia al primo ciclo d'istruzione. Carocci, Roma.

Toninato, V. \& Santovito, G. (2015) The laboratory didactics in the teaching-learning processes of life sciences. an educational project on the structure of the flower and the inflorescences phenomenon in primary school. In: EDULEARN15 Proceedings, IATED, Valencia, pp 2245-2254.

Tonon, S., Gaiotto, A. \& Santovito, G. (2013) The active teaching of life sciences in primary school: a comparative approach to the musculoskeletal system. In: EDULEARN13 Proceedings, IATED, Valencia, pp. 4289-4298.

Trevisan, T. \& Santovito, G. (2015) Teaching evolution: a laboratory approach. In: EDULEARN15 Proceedings, IATED, Valencia, pp 2234-2244.

Tura, N., Guidolin, L., Irato, P. \& Santovito, G. (2018) From cell to inheritance of characters: an introduction to classical genetics in primary school. In: INTED2018 Proceedings, IATED, Valencia. https://doi.org/10.21125/inted.2018.1076

Zanata, M. \& Santovito, G. (2020) The "Da Vinci" Biodiversity Park (Treviso, Italy). A didactic garden as innovative support to the teaching of science in secondary school. In: INTED2020 Proceedings, IATED, Valencia. https://doi.org/10.21125/inted.2020.1474.

Zandonella Necca, I., Tamino, G. \& Santovito, G. (2014) Sustainable food: an educational proposal, for key stage 3 in secondary schools, based on the assessment for learning method. In: EDULEARN14 Proceedings, IATED, Valencia, pp 7348-7356. 